\title{
Penanganan Perempuan Korban Kekerasan di Lembaga Kiprah Perempuan Yogyakarta
}

\author{
Lailul Ilham ${ }^{1}$, Casmini Casmini ${ }^{1}$ \\ ${ }^{1}$ Universitas Islam Negeri Sunan Kalijaga Yogyakarta \\ lailulilham44@gmail.com, casminiuin@gmail.com
}

Submitted: 05-10-2018, Revised : 24-11-2018, Accepted : 24-12-2018

\begin{abstract}
Woman victims of violence contrives problems on stability of psychological function which needs a quick and effective treatment in favor of being healed from trauma. This research aims to explore treatment method and its implications towards psychological aspect of women traumatized by past in KIPPER institution. It is as a descrpitive-qualitative research which uses documentation, observing, interviewing method to collect the data. This research subsequently finds that the method used is self-healing method which varies mediation-ingroup technique, taking care of self, stone and flower, and body map. The method used affects towards the psychological aspects like secure feeling, having life enthusiasm, dare to speak personally in public, having chances to live normally and freedom to gather and tell their stories with others.
\end{abstract}

Keywords: Woman victims; KIPPER; self-healing

\begin{abstract}
Abstrak: Perempuan korban kekerasan menyisakan persoalan stabilitas fungsi psikologis yang membutuhkan penanganan ektra cepat dan efektik untuk segera sembuh dari traumanya. Penelitian ini bertujuan mengeksplore metode penanganan dan implikasinya pada aspek psikologis pada perempuan korban trauma masa lalu dengan sampel di lembaga KIPPER. Penelitian ini bersifat deskriptif-kualitatif dengan pengumpulan data menggunakan metode observasi, wawancara dan dokumentasi. Hasil penelitian menunjukkan bahwa metode penanganan korban kekerasan dilakukan dengan self-healing dengan variasi teknik mediasi kelompok, merawat diri, batu dan bunga dan peta tubuh. Metode yang digunakan berpengaruh pada psikologis seperti perasaan aman, memiliki semangat hidup, berani berbicara secara personal dimuka umum, berkesempatan hidup normal, kebebasan berkumpul dan bercerita dengan orang lain.
\end{abstract}

Kata kunci: Perempuan korban kekerasan; KIPPER; self-healing

\section{Pendahuluan}

Secara universal tingkat penderita trauma berbanding lurus dengan tingginya angka kekerasan dan pelanggaran Hak Asasi Manusia (HAM), yang mengalami gangguan fisiologis dan psikologis. Aksi cepat tanggap sangat dibutuhkan dalam kasus trauma, karena keterlambatan atau kelalaian penanganan dapat semakin memperparah trauma.

Majelis Umum PBB ke-85 secara nyata melakukan upaya preventif terhadap pelanggaran HAM, yaitu dengan mendeklarasikan terkait hak hidup yang sama antara semua manusia, tidak ada istilah hak hidup laki-laki atau perempuan melainkan hak hidup manusia. Merupakan kewajiban seluruh warga negara untuk saling memperhatikan dan menghargai hak hidup orang lain, setiap pelanggaran yang dilakukan akan menciderai kebebasan fundamental orang lain serta meniadakan kemungkinan untuk menikmati hak asasi dan kebebasan mereka (Poerwandari, 2001). Regulasi tersebut menunjukkan perlindungan pemerintah terhadap perempuan dari berbagai macam kekerasan dan pelanggaran HAM dan mempertegas sanksi terhadap pelaku, regulasi tersebut juga memberikan penguatan bagi kaum perempuan dan memberikan efek jerah terhadap oknum.

Komisi Nasional Anti Kekerasan terhadap perempuan membeberkan hasil survei tahun 2001 terkait kasus pelanggaran hak asasi manusia dan dalam pemaparan hasil survei ini disebutkan ada sekitar 119.107 kasus pelanggaran terjadi pada perempuan, baik di ranah domestik atau publik. Jumlah tersebut diperoleh dari 395 lembaga layanan dan pemberdayaan 
prempuan di 33 provinsi Indonesia(Natalia Maria, 2012). Tingkat kekerasan terhadap perempuan di Indonesia relatif tinggi dan gerakan penanganan juga banyak dilakukan oleh masyarakat, baik secara personal atau institusional (kelembagaan). Tindakan-tindakan tanggap tersebut harus diapresiasi supaya terus berkelanjutan dan menunjukkan kontribusinya terhadap antisipasi kekerasan, pelanggaran HAM, serta pembentukan ruang-ruang sosial masyarakat yang lebih humanis.

Salah satu lembaga yang terlibat berkontribusi dalam proses penanganan tersebut adalah lembaga Kiprah Perempuan (KIPPER) Yogkarta yaitu lembaga rehabilitasi korban trauma dengan sistem pengelolaan yang berbeda dengan lembaga rehabilitasi pada umumnya yang cenderung dilembagakan atau individu yang direhabilitasi ditempatkan dalam satu kawasan (asrama) untuk mempermudah proses rehabilitasi. Adapan sistem rehabilitas di lembaga KIPPER dikenal dengan istilah rawat jalan yaitu perempuan yang direhabilitasi tetap bertempat di rumah masing-masing dan beraktifitas sebagaimana umumnya, namun dalam beberapa minggu sekali para anggota (perempuan) tersebut memiliki program kegiatan rutin yang bertempat di sekretariat lembaga KIPPER serta pada kesempatan-kesempatan tertentu para aktivis atau tenaga pendamping berkunjung ke rumah para anggota.

Lembaga KIPPER menarik untuk diteliti dengan serius karena tidak hanya sebagai lembaga rehabilitasi yang konsen bergerak dalam bidang pemberdayaan kaum perempuan korban pelanggaran HAM dan penanganan trauma psikologis namun lebih dari itu lembaga KIPPER juga berorientasi mendampingi kaum perempuan hingga pada tataran kemandirian diri. Modal kemamdiarian dimaksudkan supaya setelah proses pendampingan dan penanganan individu mampu beraktifitas secara mandiri tanpa menggantungkan kesejahteraan hidupnya kepada orang lain (termasuk kepada lembaga).

\section{Metode Penelitian}

Penelitian ini bersifat deskriptif-kualitatif yang memaparkan fenomena tentang perilaku, persepsi, motivasi dan tindakan lainnya secara holistik (Soetady, 2000) dalam metode dalam menangani perempuan korban trauma serta mengetahui kondisi perempuan korban trauma pasca proses penanganan.

Subjek dalam penelitian adalah pihak lembaga (terapis/aktivis) dan pihak korban trauma dengan beberapa kriteria: a) tercatat sebagai anggota KIPPER, b) Memperoleh layanan penanganan, c) mampu berdamai dengan dirinya atau telah menerima keadaan dirinya sendiri dan sembuh dari kondisi trauma, d) mampu memberikan informasi mendalam, dengan pertimbangan usia, kondisi fisik, dan kesehatan subjek. Fokus kajian pada metode lembaga KIPPER dalam menangani perempuan penderita trauma, dari tahap penerimaan, penanganan, hingga tahap pengembangan serta implikasi pasca penanganan.

Pengumpulan data dilakukan dengan observasi, wawancara dan dokumentasi. Observasi dilakukan pada proses penanganan korban trauma mulai proses konsultasi, penanganan, sampai pemberdayaan dan pelatihan, wawancara dilakukan pada korban (penderita trauma) yang telah ditangani oleh lembaga tentang faktor utama trauma secara umum, reaksi korban pra dan pasca penanganan, dan pengalaman konselor atau psikolog selama proses penanganan, meliputi aspek-aspek yang mendukung dan menghambat proses penanganan. Dokumentasi digali dari buku/majalah/brosur, foto, video dan arsip-arsip yang memuat data penanganan, perempuan yang ditangani, metode penanganan, perkembangan pasca penanganan. Data yang didapat diperiksa keabsahan data dengan teknik "Triangulasi", yaitu membandingkan kesesuaian data yang diperoleh dari berbagai teknik pengumpulan data di atas. 


\section{Kerangka Teori}

\section{Pengertian Trauma}

Trauma adalah menghadapi atau merasakan serangkaian kejadian berbahaya, baik bagi fisik maupun psikologis, yang membuat seseorang merasa tidak merasa aman, merasa tidak berdaya dan pelan dalam menghadapi bahaya (Yemy, 1991). Kemudian Kartono dan Gulo mendefinikan trauma sebagai luka berat atau pengalaman yang menyebabkan organisme menderita kerusakan. Jadi, pengalaman individu yang mengakibatkan disfungsi, baik secara fisik maupun psikologis keduanya dapat dikategorikan sebagai trauma.

Kaplan dan Sadock menjelaskan Post-Traumatic Stress Disorder sebagai stres emosional berat dan dapat terjadi pada hampir setiap orang yang mengalami kejadian traumatik. Trauma tersebut termasuk peperangan, bencana alam, penyerangan, pemerkosaan, dan kecelakaan yang serius, seperti kecelakaan mobil dan kebakaran gedung. Dan orang yang mengalami peristiwa stres pasca traumatik akan merespon peristiwa traumatik yang dialami dengan ketakutan dan keputus asaan. Individu akan terus mengenang peristiwa itu dan selalu menghindari hal-hal yang dapat mengingatkan kembali ke peristiwa tersebut (Uyun, 2015). Penelitian mutakhir tentang kajian trauma (trauma studies) mulai memahami bahwa trauma bukan semata-mata gejala kejiwaan yang bersifat individual. Trauma muncul sebagai akibat dari saling keterkaitan antara ingatan sosial dan ingatan pribadi tentang peristiwa yang mengguncang eksistensi kejiwaan (Thufail, 2015).

\section{Jenis-jenis Trauma}

Achmanto Mendatu mengidentifikasi trauma menjadi tiga, yaitu: trauma fisik, trauma post-cult, trauma psikologis (Mendatu, 2010) Trauma fisik, adalah cidera fisik yang membahayakan keselamatan akibat perubahan fisik, misal pengambilan ginjal, patah tulang, pendarahan hebat, putus tangan dan kaki, akiban penganiayaan dan lain-lain. 2) Trauma pos-cult, adalah persoalan emosional berat yang muncul ketika anggota kelompok pemujaan (cults) atau gerakan religius mengalami perasaan tidak terlibat atau tidak tergabung. 3) Trauma psikologis, adalah cidera psikologis yang biasa disebabkan oleh peristiwa luar biasa menekan atau mengancam hidupnya.

\section{Ciri-ciri Trauma}

Para ahli psikologi merumuskan identifikasi gejala atau reaksi trauma sebagai berikut, menurut Dadang Hawari ciri-ciri trauma adalah: 1) Terdapat stressor yang berat dan jelas yang akan menimbulkan gejala penderitaan yang berarti bagi hampir setiap orang. 2) Penghayatan yang berulang dari trauma itu sendiri seperti ingatan berulang tentang peristiwa itu, mimpi berulang dari peristiwa itu, timbulnya prilaku atau perasaan traumatik akibat stimulus lingkungan. 2) Penumpukan respon atau berkurangnya hubungan dengan dunia luar pasca trauma, yaitu: berkurangnya minat terhadap satu atau lebih aktivitas yang cukup berarti, perasaan terasing dari orang lain, efek perasaan yang menyempit atau efek depresif seperti murung, sedih putus asa. 3) Kewaspadaan atau reaksi terkejut berlebihan. 4) Ganguan tidur (disertai mimpi dan gelisah). 5) Daya ingat atau sukar konsentrasi. 6) menghindari aktivitas yang membangkitkan ingatan tentang peristiwa trauma itu. 7) Peningkatan-peningkatan gejala jika dihadapkan dengan peristiwa yang menandakan atau menyerupai peristiwa trauma itu (Hawari, 1997).

\section{Faktor Trauma}

Trauma memiliki dua faktor, pertama: Faktor Internal: Badan National Institute of Mental Health, menyatakan bahwa fisik dan psikologis merupakan faktor yang saling berhubungan dan mempengaruhi, dan keduanya merupakan serangkaian hubungan internal dari struktur otak yang berbentuk sirkuit dan mempunyai fungsi utama dalam motivasi dan emosi (Saputra, 2012). Menurut Bullman dan Peterson (ahli kesehatan dan psikologi), faktor psikologis lain yang mempengaruhi perkembangan Post-Traumatic Stress Disorder (PTSD) adalah peran kognisi, yaitu cara pandang individu terhadap pengalamannya. Pemberian arti 
atau makna terhadap sebuah peristiwa traumatik akan mengarahkan respon-reaksi individu dalam menghadapi stresor. Individu yang tidak dapat mengarahkan pada pemberian arti positif maka kecenderungan PTSD lebih besar.

Kedua: faktor Eksternal. Boulware menyatakan bahwa PTSD dapat terjadi setelah peristiwa traumatik besar dan keseriusan stressor menentukan kecenderungan PTSD. Tingkat keseriusan stresor pada dasarnya adalah subjektifitas individu yang mengalaminya namun sering kali tingkat keseriusan stresor dipandang seberapa jauh sebuah kasus atau kejadian dapat membuat banyak orang trauma dan mengalami stres (Saputra, 2012). Dalam buku "hyglene mental dan kesehatan mental dalam islam" Kartini Kartono dan Jenny Anny Andari menjelaskan bahwa trauma disebabkan oleh pengalaman yang sangat menyedihkan atau melukai jiwanya, sehingga pengalaman tersebut mengakibatkan perubahan individu secara radikal (Andari, 1989).

\section{Penanganan Trauma}

Secara literer penanganan diartikan sebagai proses, cara, perbuatan menangani; penggarapan dengan orientasi kepada posisi-situasi yang lebih baik. Penanganan yang dimaksud adalah segala bentuk respon yang dilakukan dalam membantu individu atau perempuan korban trauma kekerasan, supaya segera mendapat penanganan dan sembuh dari perilaku-perilaku abnormal serta perilaku lain yang lebih fatal. Tujuan akhirnya mengembalikan korban pada kondisi hidup sebagaimana individu pada umumnya (Yemy, 1991).

Adapun penanganan paling mendasar adalah memberikan pemahaman kepada korban bahwa kasus yang menimpa bukan semata kelalaian atau kelemahan dirinya melainkan ketentuan Tuhan yang mesti dihadapi dengan tegar, tidak putus asa, terus bertawakal dan senantiasa mensyukuri nikmatnya (Affandi, 2010) Penanganan bisa berupa pendampingan fisiologis (pengobatan fisik: kesehatan), pendampingan psikologis (pemberian terapi-terapi psikis), dan pendampingan hukum (pemberian bantuan memperoleh hak hukumnya). Adapun metode penanganan sebagaimana tersebut di bawah ini:

\section{a. Hipnoterapi}

Persoalan traumatik berasal dari permasalahan yang tersimpan di alam bawah sadar dan metode hipnoterapi merupakan metode penanganan yang fokus menganalisis aspek alam bawah sadar individu sehingga akan ditemukan permasalahan dasar dan individu diarahkan untuk menyelesaikan traumatik mereka secara mandiri. Berdasarkan data di atas metode pananganan hipnoterapi terbukti efektif dalam mengatasi persoalan trauma. Terdapat lima tahapan dalam hipnoterapi yaitu pengkajian, induksi, deeping, terapi pikiran, terminasi. Tahap deeping klien dibawa masuk ke alam bawah sadarnya. Pada tahap terapi pikiran, terapis dapat memberikan keyakinan positif untuk menghilangkan stress pasca trauma yang dialami (Rakhmawati, 2014).

Stres pasca trauma umumnya terjadi selama 6 bulan, dan gejala setiap fase (perbulan) berbeda-beda. Pada minggu awal stress cenderung fase akut sehingga hipnoterapi belum bisa dilakukan karena keadaan psikologis konseli belum stabil. Idealnya hipnoterapi dilakukan pasca berakhirnya fase akut yaitu ketika konseli bisa fokus dan bisa diajak bekerjasama. Faktor keberhasilan hipnoterapi adalah kemampuan konseli untuk dihipnosis, harapan terhadap hipnoterapi, dan kerjasama dengan terapis. Hipnoterapi akan lebih efektif jika dikolaborasikan dengan pendekatan psikoanalisis karena dalam hipnosis sugesti positif bekerja di alam bawah sadar sehingga perilaku negatif perlahan dirubah menjadi positif.

\section{b. Self-Healing}

Self-healing merupakan metode penanganan yang diterapkan pada fase pemulihan diri (umumnya dari gangguan psikologis: trauma, stress, dll), didorong dan diarahkan 
oleh pasien sendiri, biasanya hanya dipandu oleh insting. Proses tersebut menghadapi nasib campuran karena sifat amatir, meskipun motivasi diri merupakan aset utama. Nilai penyembuhan diri terletak pada kemampuan dan pengalaman unik serta persyaratan individu. Proses ini dapat dipercepat dengan teknik introspeksi seperti meditasi, yoga dan kegiatan-kegiatan yang bersifat relaksasi dan refleksi. Penyembuhan diri adalah fase akhir Terapi Gestalt.

Metode self-healing disebut juga terapi healing, yaitu metode penanganan trauma (stres, depresi, dll) yang menitik-beratkan keberhasilan terapi kepada klien. Dalam konsep terapi healing konselor tidak memiliki kapasitas mengatur atau menentukan proses terapi selain mengikuti kehendak konseli. Perlu diketahui bahwa setiap individu memiliki naluri penyembuhan diri, artinya dalam setiap orang yang menjadi korban akan memperbaiki bagian yang rusak dengan sendirinya. Naluri tersebut tidak dapat dipungkiri karena kodrat organisme antara tubuh dan psikologis.

\section{c. Psikoterapi}

Para terapis percaya pada tiga tipe psikoterapi yang efektif digunakan untuk penanganan Post-Traumatic Stress Disorder PTSD, yaitu: anxiety management, cognitive therapy, exposure therapy Anxiety management, terapis mengajarkan keterampilan untuk membantu mengatasi gejala PTSD melalui: 1) relaxation training; belajar mengontrol ketakutan dan kecemasan dan merelaksasi otot-otot utama, 2) breathing retraining; belajar bernafas dengan perut secara perlahan dan menghindari bernafas tergesa-gesa yang menimbulkan perasaan tidak nyaman, 3) positive thinking dan self-talk; belajar menggantikan pikiran negatif kepada pikiran positif ketika menghadapi stresor, 4) assertiveness training; belajar mengekspresikan harapan, opini dan emosi tanpa menyalahkan orang lain, 5) thought stopping; belajar mengalihkan pikiran ketika sedang memikirkan hal-hal yang membuat stres (Lestari, 2016).

Cognitive therapy yaitu membantu merubah konsep berpikir konseli, seperti kesalahan berpikir korban perampokan yang menyalahkan dirinya sebab tidak hati-hati. Tujuan terapi kognitif adalah mengganti pikiran irasional kepada pikiran rasional (realistis) untuk mencapai emosi yang lebih seimbang. Exposure therapy yaitu membantu klien menghadapi ingatan atau emosi yang memunculkan efek traumatik. Terapi dapat dilakukan dengan cara: exposure in the imagination, yaitu meminta konseli mengulang cerita secara detail sampai tidak mengalami hambatan menceritakan, pengulangan disertai penyadaran supaya membantu klien menyadari bahwa situasi lampau tidak menakutkan, tidak berbahaya dan dapat diatasi. Dan exposure in reality, yaitu membantu menghadapi situasi yang sekarang aman tetapi ingin dihindari karena menyebabkan ketakutan yang kuat (misal: kembali ke rumah setelah terjadi perampokan di rumah).

\section{Penanganan Trauma Perspektif Bimbingan dan Konseling Islam}

Sebagai dasar analisis dalam penelitian ini, kasus trauma ditarik ke dalam konteks isu kesetaraan, gender dan kekerasan. Ide kesetaraan manusia sudah seharusnya mendapatkan elaborasi lebih luas berkaitan dengan relasi laki-laki dan perempuan dan beberapa tahun terakhir relasi gender sedang diperdebatkan serius dan menimbulkan ketegangan di internal umat Islam. Relasi gender perlu terus dikomunikasikan sebab dewasa ini sering terjadi realitas sosial dan kebudayaan yang cenderung menempatkan perempuan dalam posisi subordinat (patriarki).

Berdasarkan bahasa kontemporer, kaum perempuan berada dalam posisi subordinat, marginal dan terdiskrimasi. Posisi tersebut sering mengakibatkan kaum perempuan rentan penindasan dan kekerasan. Perdebatan relasi gender dikalangan muslim semakin mencuat berkaitan dengan pernyataan sebagian masyarakat yang melegitimasi posisi subordinat perempuan dengan mengatas-namakan agama. Pemikiran tersebut dikritik oleh pemikiran baru yang menyeru tegaknya prinsip keadilan dan kesetaraan manusia sebagaimana 
diajarkan agama tauhid dan nilai-nilai kemanusiaan (Muhammad, 2004). Akibat tidak semua pelanggaran terakomodir atau tidak dapat diantisipasi sehingga banyak orang yang diciderai normalitas hidupnya, dan itu menjadi kewajiban sesama umat manusia untuk saling memberi bantuan dan dukungan sosial.

\section{a. Perintah saling menjaga hak hidup orang lain}

Islam sebagai agama tauhid (monoteisme) telah mengindikasikan penolakan terhadap tindakan mengistimewakan atau mengunggulkan satu atas yang lain. Dalam pandangan Islam, keistimewaan (superioritas) manusia hanya dapat dibenarkan sejauh menyangkut tingkat pengakuan atas ke-esa-an Tuhan. Wujud pengakuan dapat dilihat dari sejauh mana tingkat pengabdian manusia kepada-Nya semata, baik pada level individual maupun sosial (Muhammad, 2004). Berangkat dari gagasa di atas maka sikap atau persepsi yang merendahkan, melecehkan, melukai merupakan pelanggaran terhadap hak-hak Tuhan. Maka wajar jika Tuhan mengancam keras cara pandang tersebut dan dinyatakan sebagai suatu kezaliman. Sebagaimana firman Allah:

"hai orang-orang yang beriman, janganlah ada satu kelompok laki-laki diantara kamu memperolok-olokkan kelompok laki-laki lainnya, karena kemungkinan mereka inilah yang lebih baik. Begitu juga janganlah ada satu kelompok perempuan memperolok-olokkan perempuan lainnya karena mungkin mereka inilah yang lebih baik. Janganlah kalian saling mencela dan menjuluki dengan nama-nama yang buruk. Betapa buruknya jika setelah menjadi orang-orang beriman kalian saling menjuluki dengan nama-nama yang buruk. Barang siapa tidak menghentikan perbuatan yang seperti ini adalah orang-orang yang zalim.(QS. Al-Hujurat/49: 11).

\section{b. Perintah saling membantu sesama manusia}

Perintah saling membantu (ta'awun) merupakan suatu yang familiar di tengah masyarakat karena sering disampaikan di mimbar-mimbar dakwah bahwa sebagai sesama manusia sudah seharusnya bersikap saling membantu dalam urusan kebaikan, karena tindakan tersebut merupakan bagian dari tugas kemanusiaan dan idealnya manusia harus memperhtikan dan melaksanakan perintah Allah tersebut. Sebagaimana firman Allah yang artinya "Dan tolong-menolonglah kamu dalam (mengerjakan) kebajikan dan takwa, dan jangan tolong-menolong dalam berbuat dosa dan pelanggaran. Dan bertakwalah kamu kepada Allah, sesungguhnya Allah amat berat siksa-Nya." [Al-Mâidah/5: 2].

Berdasarkan pemahaman dan ayat di atas, melayani orang yang sedang butuh bantuan (selain maksiat kepada Allah) merupakan suatu kewajiban yang harus ditunaikan dan dasar leyanan tersebut tidak hanya atas perintah Allah tapi sebagai penggilan kemanusiaan. Dalam kontek penelitian, korban adalah pihak yang butuh simpati dan kepedulian atau trauma yang dialami membutuhkan keterlibatan banyak pihak dalam proses pemulihan. Allah memerintahkan hambanya untuk membantu orang yang kesulitan dan membutuhkan bantuan. Dan penderita trauma termasuk orang yang membutuhkan motivasi dan penanganan dari permasalahan hidup yang sedang dihadapinya.

Perempuan yang menderita trauma cenderung menarik diri dari lingkungan sekitar dan sering atau mudah merasa mendapat tekanan dari peristiwa sekitar. Kemudian akibat perasaan tertekan tersebut biasanya individu memunculkan reaksi sikap keras, suka bertindak kasar, dan kembali mengalami traumatik. Kondisi tersebut terus terjadi berulang-ulang hingga penderita trauma sulit mengalami kebahagiaan sebagaimana orang-orang pada umumnya. Sehingga kondisi tersebut butuh reaksi cepat dan dukungan dari orang-orang sekitar supaya kondisinya segera pulih dan dapat surfive dan menjalani hidup bahagia tanpa tekanan masa lalu. 


\section{Hasil dan Pembahasan}

Berdasarkan hasil penelitian terhadap penangan korban trauma di lembaga Kiprah Perempuan (KIPPER) yaitu menggunakan metode Healing atau self-healing, dikenal dengan istilah trauma healing. Metode healing merupakan terapi trauma yang memanfaatkan kemampuan dasar individu, baik kesediaan untuk diterapi, keinginan sembuh, dan upaya-upaya yang telah dilakukan demi kesembuhan trauma yang sedang dideritanya. Berdasarkan prinsp dasar terapi helaing sehingga keberhaslan proses penanganannya sangat ditentukan oleh korban sendiri atau atas kerjasama antara terapis dan yang diterapi. Lembaga KIPPER memiliki metode penanganan sederhana namun berimplikasi besar terhadap kesembuhan psikologis, emosi dan kognisi para penderita trauma.

Sebagaimana pernyataan ibu Erlin bahwa "supoyo ora jelleh sesasi pisan, supoyo gak sampe numpuk rindunya itu, kita adakan pertemuan, tapi sebetulnya pertemuan itu sendiri sakjane ming ngumpulke balung pisah, belum ada tujuan-tujuan tertentu seperti yang saya omongin, cukup bisa bertenu saja sudah seneng, terus diperjalalan waktu bisa disimpulkan bahwa bertemu itu sendiri sudah merupakan healing, ya kan?, merupakan penyembuhan tersendiri". Perkumpulan sederhana yang diinisiasi oleh para aktifis KIPPER ternyata menjadi media terapi trauma tersendiri, dan belum ditemukan dalam teori-teori penanganan sebelumnya. Sebab, dari kegiatan perkumpulan tersebut ditemukan potensi untuk merumuskan model penanganan baru yang lebih efektif dalam menyembuhkan trauma, hal tersebut menunjukkan bahwa terapi healing di lembaga KIPPER tidak sebagaimana umumnya yang terkesan formal, terstruktur dan teknis. Konsep yang dimaksud adalah pemanfaatan kegiatan perkumpulan menjadi media healing, yaitu anggota disediakan kesempatan luas untuk berkumpul, bersosialisasi, saling bercerita pengalaman masing-masing, dan diadakan kegiatan arisan sebagai motivasi dan sarana menumbuhkan kesadaran kolektifitas para anggota.

Adapun metode healing yang diterapkan di lembaga KIPPER dilaksanakan dengan beberapa teknis, antara lain:

\section{a. Memediasi Perkumpulan Perempuan Korban Trauma}

Kegiatan perkumpulan merupakan momen yang secara sadar dan terstruktur diinisiasi oleh lembaga KIPPER sebagai upaya mempertemukan para perempuan penderita trauma dan memberikan ruang Sebagaimana salah satu misi KIPPER adalah mengumpulkan atau memberikan ruang terbuka supaya mereka dapat bersama-sama saling berbicara, saling bertindak dan saling memberikan dukungan menuju kehidupan yang lebih baik. Sebagaimana pernyataan ibu Pipit Ambarmirah bahwa "awal berdirinya KIPPER tidak terfikirkan untuk menangani trauma, ketika KIPPER berdiri hanya karena mereka membutuhkan saluran untuk mengobrol dengan bebas, yang disitu anggotanya sama-sama tau tidak usah menyembunyian diri, terus mereka bisa berkumpul dua bulan sekali dan ngobrol dengan bebas. Ibu-ibu yang aktif berkumpul terlihat memiliki semangat hidup dan itu terjadi dalam posisi mereka tidak sadar." (Ambarmirah, 2016).

Pernyataan narasumber menunjukkan bahwa lembaga KIPPER memiliki strategi tersendiri dalam mengatasi kasus trauma yaitu dengan memediasi para korban trauma supaya dapat berkumpul karena berkumpul diyakini tidak sebatas memberikan ruang pertemuan melainkan juga dapat mendorong para korban untuk saling memotivasi menuju stabilitas fungsi psikologis masing-masing. Sehingga para korban tidak (betul-betul) sadar bahwa dirinya sedang dalam proses penanganan sebab proses penyembuhan berjalan mengalir tanpa ada teknis baku yang mengikat. Semakin sering intensitas berkumpul maka para korban dengan sendirinya semakin mendapatkan kepercayaan diri untuk segera pulih dan kembali hidup normal. Kemudian dikuatkan lagi bahwa "jadi bagaimana kemudian tidak hanya melakukan pertemuan, tapi gimana caranya pertemuan itu tidak hanya kumpulkumpul saja, tidak hanya arisan, tidak hanya simpan pinjam, tapi secara tidak langsung 
juga membuat penyembuhan. Dan ternyata salah satu caranya adalah dengan bercerita secara terus menerus. Kemudian mendokumentasikan apa yang mereka ingin dokumentasikan. Kesini-kesini kan kemudian tidak hanya mulai menyadari ternyata perkumpulan ini bisa dimanfaatkan untuk menyembuhkan trauma korban yang tidak terlalu tinggi dengan perkumpulan rutin ini”. (Ambarmirah, 2016).

Berdasarkan ungkapan narasumber semakin menegaskan bahwa perkumpulan menjadi teknik baru dalam metode penanganan, yang implikasinya cukup signifikan terhadap proses pemulihan kondisi traumatik. Kemudian ibu Pipit Ambarmirah memberikan informasi terkait bentuk-bentuk atau data kemajuan yang tampak pada korban setelah mengikuti perkumpul rutin, yaitu:

1) Kemampuan berbicara dan bercerita, para korban semula tidak punya keberanian bercerita pengalaman yang membuat dirinya trauma namun dengan kegiatan perkumpulan mereka perlahan lebih terbuka dan berani. Pertama-tama mereka diarahkan untuk saling bercerita kepada satu orang lainnya dan dilakukan secara berulang-ulang hingga mereka benar-benar terbiasa. Setelah mereka berani bercerita kemudian diminta untuk bercerita dihadapan rekan-rekan satu kelompok. Berawal dari metode tersebut akhirnya mereka mampu berbicara di hadapan publik, tidak hanya di depan para anggota lembaga tapi ada sebagian sampai menjadi pembicara dibeberapa perguruan tinggi dengan tema-tema yang tidak jauh dari latar belakang yang mereka alami.

2) Kemampuan berpendapat, akibat trauma yang telah mengakar kuat mengakibatkan mereka ketakutan untuk bercerita (stresor) apalagi sampai mengutarakan pendapat. Namun dengan perkumpulan mereka berkesempatan saling bercerita serta saling memberi saran kepada rekannya yang lain, berawal dari kegiatan tersebut mereka menjadi terbiasa memberi masukan sehingga sedikit demi sedikit mereka berani mengutarakan pendapatnya, berawal dari satu orang hingga di hadapan banyak orang. Kemudian perempuan-perempuan yang telah pulih dan mampu berdamai dengan masa lalunya diarahkan menjadi motivator bagi rekannya yang lain.

3) Kemampuan aktif di lembaga, dengan menjadi bagian atau anggota lembaga KIPPER para perempuan merasa memiliki kesempatan hidup bahagia setelah beberapa tahun hidup terisolir dari ruang sosial. Perkumpulan membuat mereka saling berbicara, saling bercerita, saling berbagi (materi/imateri), saling tertawa dan bahagia. Karena kondisi perkumpuan membuat mereka merasa aman dan nyaman sehingga mereka selalu merindukan kebersamaan itu, bahkan terkadang mereka meminta kepada pihak lembaga supaya ditambah kegiatan perkumpulannya.

4) Kemampuan memberi motivasi pada perempuan lain. Bagi para perempuan yang telah pulih dari trauma dan mampu memberikan motivasi kepada perempuan-perempuan yang lain, mereka dimediasi oleh lembaga untuk membantu dalam proses penyembuhan korban trauma yang lain. Sebab akan berbeda dorongan-dorongan yang diberikan oleh perempuan yang sebelumnya pernah mengalami trauma dan berhasil sembuh, harapannya mereka tidak hanya sembuh melainkan mampu mengajak rekannya untuk segera pulih dan bersama-sama merencanakan hidup yang lebih baik.

Progresifitas hidup yang terjadi pada para perempuan (traumatik) tidak lepas dari kegiatan perkumpulan serta kegiatan-kegiatan lainnya, sebab dalam perkumpulan anggota mendapat jaminan kebebasan dan keamanan untuk melakukan banyak hal seperti bersosialisasi, bercanda lepas, dan berbicara apa saja. Kebabasan tersebut membuat mereka merasakan kembali keleluasaan hidup setelah sekian lama tidak merasakan kebahagiaan akibat kehawatiran dan teror stressor yang terus meningkat. Kemudian lembaga KIPPER menjalin kerjasama dengan beberapa lembaga seperti lembaga AJAR (Asia Justice and Right) dan lembaga Rifka Anisa, dari pengalaman-pengalaman yang diperoleh kemudian 
KIPPER melakukan evaluasi internal dan berbenah lalu merumuskan kembali program yang lebih spesifik pada penanganan truma.

\section{b. Metode Merawat Diri}

Metode Merawat Diri, yaitu mengarahkan penderita trauma untuk lebih memperhatikan diri secara fisiologis, supaya fisiknya selalu stabil dan sehat. Sebagaimana prinsip dasar penanganan bahwa keberhasilan atau kesembuhan trauma ditentukan oleh kemampuan dan semangat individi yang diterapi. Kecepatan proses penanganan dapat didukung oleh teknik penguatan seperti meditasi, yoga, dan kegiatan-kegiatan yang bersifat relaksasi dan reflektif. Adapaun metode merawat diri sebagai berikut (Galuh Wandita, 2015)

1. Bagaimana Mengatasi Emosimu?

Kegiatan diawali dengan menanyakan cara mengatasi kecemasan, stress, dan masalah psikis lain, yang biasa dilakukan oleh peserta. Selanjutnya peserta diajarkan latihan pernafasan sekaligus diberi contoh gerakannya.

2. Memegang Jari

Peserta diajak melakukan peregangan jari-jari, menutup satu jari dengan jari tangan lain kemudian ditahan. Kemudian menyuruh peserta menutup mata, bernafas yang dalam, lalu dimainkan alunan musik yang lembut. Relaksasi tersebut dapat memberikan ketenangan dan kedamaian pada mereka.

3. Peregangan Sederhana

Grakan peregangan dimaksudkan untuk melepas ketegangan dan menjernihkan pikiran, dan tekniknya antara lain (Peregangan, 2016):

a) Peregangan Bahu: Melepas Ketegangan Leher dan Bahu

Pertemukan jari-jari lalu angkat ke atas kepala dengan telapak tangan menghadap ke atas, lengan segaris dengan telinga dan pandangan ke depan. Kemudian jatuhkan lengan kesisi badan dan putar bahu ke depan dan belakang. Lakukan semua instruksi dan ditahan dalam lima kali pernafasan.

b) Regangkan Dada Anda

Berdiri dengan jarak kaki selebar mungkin, gapai tangan di belakang, genggam kedua tangan dibawah posisi punggung, angkat kepalan tangan setinggi mungkin (dibelakang). Tarik tulang balikat hingga mendekat. Setiap posisi ditahan selama lima pernafasan.

c) Regangkan Otot-otot Trisep dan Bahu Anda

Angkat tangan kanan diatas kepala, tekut siku agar tangan kanan menyentuh belakang bahu kiri, tekan siku dengan tangan kiri. Tahan posisi selama 20 detik, kemudian ganti tangan lain.

d) Berdiri Membungkuk ke Depan Melepaskan Ketegangan Tulang Punggung dan Leher Kaki berjarak selebar panggul, tekuk badan ke depan sampai posisi kepala menggantung, apabila paha belakang terasa tegang, tekuklah lutut. Kemudian kembali keposisi tegak dan angguk-anggukkan kepala. Cobalah untuk relaksasi dalam pose ini selama lima nafas penuh.

Mebiasakan melakukan metode merawat diri membuat tubuh lebih rileks dan bugar, dan dalam kondisi tubuh yang rileks korban penderita trauma akan lebih mudah menerima masukan dan kerja kognitifnya juga lebih stabil, ini dapat membantu menstabilisasi fisik dan akan berimplikasi pada kesehatan psikologis. Sebagaimana pernyataan ibu HT bahwa "yang saya pake itu tentang kesehatan mas, yang terang. Di kesehatan itu dari PULIH kan ada pelajaran ini, kalo stres ini ya, ada catatan pijitan tangan, itu saya gunakan. terus pernafasan yang tidur ndak make bantal, itu saya gunakan karena tadinya saya kan kalo anget suka sesak gutu ya, itu sekarang kok sembuh, itu yang saya gunakan." (HT, 2016). 
Data tersebut menunjukkan bahwa teknik merawat diri dan relaksasi baik bagi kesehatan dan mampu menyembuhkan penyakit yang sedang diderita. Sebagaimana pernyataan Ibu HT kepada penulis bahwa di usianya yang sudah 79 tahun beliau masih mampu melakukan banyak hal bahkan sesuatu yang secara normal sudah tidak bisa dilakukan oleh orang-orang seusianya.

\section{c. Metode Batu dan Bunga}

Metode tersebut sangat efektif untuk menggali informasi dari penderita trauma yang tidak mampu bicara atau merespon lingkungan termasuk menjawab pertanyaan sebab metode tersebut hanya butuh kemampuan memahami dan mengisyaratkan, tidak membutuhkan komunikasi verbal. Tekniknya sebagai berikut (Galuh Wandita, 2015):

1. Membentuk Lingkaran: para peserta terapi diajak duduk berbentuk lingkaran, kemudian masing-masing diberikan 12 batu dan 12 bunga.

2. Menjelaskan Diagram: disediakan satu lembar kertas besar dengan diagram di tengah lingkaran kemudian dijelaskan cara kerja diagram tersebut. Dijelaskan empat kuadran dan masing-masing arti kuadran; kebenaran (kiri atas), keadilan (kanan atas), pemulihan (kiri bawah), bebas dari kekerasan (kanan bawah). Dan dijelaskan pula ketiga lingkaran konsentris: pribadi, keluarga, dan masyarakat.

3. Diri Sendiri dan Kebenaran: diawali dari kuadran kebenaran yaitu peserta diajak menjawab pertanyaan "apakah mereka telah mampu atau belum mampu menerima kebenaran atas apa yang mereka alami (menjadi korban kekerasan)". Sambil berjalan mengelilingi lingkaran, setiap peserta diminta menempatkan batu atau bunga dalam lingkaran kuadran kebenaran, sambil menjelaskan mengapa mereka memilih batu atau bunga.

Keterangan:

Batu : tanggapan negatif (tidak/belum)

Bunga : tanggapan positif (ya/sudah)

4. Keluarga dan Kebenaran: setelah lingkaran "kebenaran diri" lalu pindah ke lingkaran berikutnya tentang "pengakuan keluarga atas pengalaman perempuan yang bersangkutan" dan mengulangi kembali latihannya. Peserta diberi waktu cukup untuk menjelaskan.

5. Masyarakat dan kebenaran: setelah lingkaran "kebenaran keluarga" kemudian pindah ke lingkaran masyarakat tentang "Bagaimana pengakuan masyarakat atas pengalaman mereka", dengan mengulangi kembali proses yang sama untuk masing-masing kuadran batu dan bunga.

6. Bandingkan: setelah semua peserta menjawab pertanyaan kemudian lihat kesamaan dan perbedaan yang muncul. Lebih banyak batu atau bunga (apa artinya?), kemudian pada diagram apa yang memiliki campuran batu dan bunga (mengapa itu terjadi?).

7. Rangkum: sesi terakhir merupakan tugas fasilitator memberikan rangkuman atas jawaban dari pengalaman para perempuan dengan mengidentifikasi kesamaan dan perbedaan utama.

Menggunakan metode batu dan bunga dapat mempermudah penderita trauma (termasuk trauma akut) dalam mengungkapkan pengalaman atau kondisi yang dialami. Sebagaimana pernyataan Ibu FK bahwa "korban yang trauma itu kan sulit menceritakan yang dialami mas, apakah dianya lagi takut, lagi sedih, atau lagi khawatir. Karena rasa takutnya yang sudah tidak karuan itu, membuat dia takut pada siap aja, bisa jadi kepada mas-nya mungkin, walaupun sebenanya mau membantu. Naah, dengan cara itu, batu-bunga itu, orang yang trauma itu cuma diminta naruh batu atau bunga dalam garis-garis itu, tapi itu dipandu oleh anunya, petugas yang menerapi" (FK, 2016). Berdasarkan data wawancara tersebut dapat dilihat bahwa metode batu dan bunga memberikan kemudahan kepada penderita trauma untuk mengungkapkan perasaannya dan memungkinakan bagi peneliti 
untuk mendpatkan informasi yang detail dan mendalam terkait korban kekerasan walaupun kondisi korban dalam keadaan trauma dan tidak mampu berkomunikasi aktif (verbal).

\section{d. Metode Peta Tubuh}

Metode Peta Tubuh (Galuh Wandita, 2015), memiliki fungsi yng sama dengan metode batu dan bunga yaitu penelitian tanpa melalui wawancara. Metode ini dilakukan dengan simbol-simbol gambar dan teknisnya sebagai berikut:

1. Persiapan: setiap peserta diarahkan mencari pasangan satu persatu, kemudian diberikan kertas flep besar, spidol besar (hitam), spidol kecil (kuning dan biru).

2. Menggambar Peta Tubuh: setiap pasangan diarahkan mencari lokasi yang nyaman, kemudian satu orang diarahkan berbaring diatas hamparan kertas flep, dan rekan satunya menarik garis disekeliling tubuh dengan spidol besar hingga membentuk siluet dan terus bergantian. kemudian disetiap siluet ada nama peserta.

3. Mewarnai Peta Tubuh: meminta peserta untuk menyelesaikan siluetnya dengan menambahkan warna atau simbol pada bagian-bagian yang berbeda dari tubuhnya.

Gunanakan Biru: untuk mewarnai tubuh yang memiliki atau masih merasakan penderitaan dan kesedihan.

Gunakan Kuning: untuk mewarnai bagian tubuh yang memiliki atau merasakan kebahagiaan atau kekuatan.

4. Diskusi: setelah siluet selesai dan diwarnai, ajak peserta membicarakan peta tubuh masing-masing.

5. Membandingkan Peta: setelah semua peserta berbicara, kemudian tanyakan kesamaannya dengan teman yang lain, dan menanyakan bagaimana cara merubah bagian tubuh yang berwarna biru bisa menjadi kuning.

6. Mendiskusikan Rekomendasi Umum 30 tentang Cedaw: menjelaskan kepada peserta bahwa yang mereka alami juga dialami oleh banyak perempuan lain di dunia, hingga ada kesepakatan internasional untuk mencegah kekerasan terhadap perempuan.

7. Pengingat: tahap akhir memberi saran kepada peserta untuk membawa hasil sesi pertama dalam sesi pertemuan selanjutnya.

Konsep dasar dan teknis pelaksanaan metode Peta Tubuh dan Batu-Bunga hampir sama dan sama-sama memanfaatkan kemampuan respon korban dengan simbol-simbol dan gambar, sehingga dalam metode ini peserta tidak diminta untuk menceritakan langsung halhal yang menimpa dan membuat dirinya mengalami tekanan batin. Sebagaimana diungkapkan Ibu HT bahwa "Kalo perempuan trauma karena diperkosa umpamanya, terus perempuan itu merasa ketakutan, mengurung diri di kamar, takut pada lelaki, jadi kan sulit kalo diminta informasinya. Apalagi kan jelas kalau seksual itu bagian tubuh yang diciderai yang mana, jadi perempuan kemungkinan besar akan merasa malu untuk menceritakan itu. Tapi kalu dengan menggambar nanti kan itu lebih mudah, rasanya tidak terlalu saru, dan korban tinggal menunjuk bagian tubuhnya dan memberikan warna biru, ada juga yang merah. Iya kan”. (HT, 2016).

Data wawancara tersebut menunjukkan bahwa kondisi trauma akut bukan suatu kondisi akhir, yang tidak dapat didampingi atau bahkan ditangani lagi. Sebab prinsip dasarnya adalah semua metode penanganan dapat dilakukan jika individu yang diterapi sudah mampu bekerjasama dengan tenaga terapis, salah satu bentuk kerjasama paling dasar adanya kemampuan berkomunikasi. Namun pada penderita trauma akut, sekalipun sudah tidak memiliki keberanian untuk berbicara atau bercerita tentang pengalaman (stressor) yang telah menimpa dirinya ternyata masih bisa dilakukan dengan kedua metode tersebut yaitu melalui komunikasi non-verbal (isyarat). Metode ini juga efektif dalam penggalian data dari perempuan korban kekerasan seksual, dimana mereka pasti mengalami kesulitan besar untuk menceritakan sebab menyangkut organ vital dan paling sensitif dari tubuhnya, sehingga kedua metode tersebut mempermudah bagi mereka dalam mengungkapnya. 


\section{Implikasi Penanganan Terhadap Korban Trauma}

Terminologi implikasi mengindikasikan sebuah progresifitas atau kondisi lebih baik yang terjadi pada individu pasca mendapatkan tretmen atau penanganan. Setiap penanganan memiliki potensi yang berbeda namun secara umum setiap penanganan akan memunculkan reaksi psikologis, emosional dan kognitif yang lebih baik dari kondisi sebelumnya. Adapaun identifikasi implikasi penanganan berdasarkan tiga aspek yaitu psikologis, emosional, dan kognitif. Berikut hasil data lapangan:

\section{Psikologis}

Proses pengamatan terhadap kondisi psikologis dilakukan setelah peroses penanganan selesai diberikan kepada korban trauma dan idealnya pasca penanganan korban akan menunjukkan kondisi psikologis yang lebih stabil dan terkontrol. Misalkan kondisi psikologis semula cenderung labil, mudah tersinggung, minder, ketakutan dan khawatir berlebihan, namun setelah penanganan memunculkan kondisi berbeda yaitu adanya motivasi pada korban untuk segera pulih, dapat hidup normal dan kondisi tersebut menjadi motivasi bagi perempuan-perempuan lain. Berdasarkan pernyataan Ibu HT "Setelah saya ikut dengan KIPPER, saya merasa memiliki banyak teman, dan secara tidak disangka rasa percara diri saya pelan-pelan muncul dan saya berani berbicara didepan orang, walaupun sebenarnya dari dulu saya juga sudah bisa berbicara didepan banyak orang tapi kalo dulu masih berfikiran kalau orang-orang masih merasa kalau saya itu orang jelek" (HT, 2016).

Beradasarkan wawancara tersebut terdapat satu kata kunci dari berbagai kemajuan yang dialami Ibu HT yaitu "percaya diri", perasaan yang perlahan muncul dan memberikan keberanian bagi narasumber untuk berbicara dan membuktikan di depan halayak umum bahwa dirinya adalah orang baik dan bisa menjadi warga masyarakat yang baik. Saat mengalami trauma, Ibu HT tidak memiliki kebaranian untuk menjelaskan bahwa dirinya orang baik dan persepsi masyarakat tentang dirinya adalah keliru, namun sekarang beliau sudah sembuh dan mampu berdamai dengan dirinya serta mampu hidup dengan normal.

Sebagaimana juga diungkapkan Ibu FK bahwa "Saya masih bisa berjalan sendiri, bisa mandiri, maka saya harus jalani, untuk mengisi kekosongan waktu, mengisi pikiran biar gak bebel, pikiran biar bisa selalu muter, jadi usaha untuk tidak pikun, hahaha. Dengan sisa-sisa kekuatan yang saya miliki, kegiatan saya yaa, disampig saya jahit, kalau mantap jahit ya sehairan gak berhenti kalau lagi tidak ada minat, motong saja kalo gak ada minat, udah ditinggal aj, itu sebagai obat diri pribadi saya untuk saya tidak sakit-sakitan, supaya saya juga tidak pikun, supaya untuk tidak melupakan masa laluku”. (FK, 2016).Pernyataan tersebut semakin mengokohkan bahwa semangat hidup yang muncul dalam diri mereka menjadi modal kekuatan terbesar untuk perubahan hidup yang lebih bermakna dan bermanfaat yaitu terus melakuakan hal-hal positif bagi dirinya sendiri, orang lain, dan lingkungan sekitar. Akibat dari kondisi hidup yang melarat dan penuh tekanan (psikologis) membuat Ibu FK memiliki ketahanan dan semangat hidup di atas orang-orang pada umumnya, sebab segala kondisi dan pengalaman yang telah menimpa hidup mereka dijadikan pembelajaran untuk hidup lebih bermakna.

\section{Emosional}

Gocangan jiwa yang dirasakan korban setelah mengalami peristiwa kekerasan menimbulkan reaksi emosi yang tidak stabil seperti munculnya rasa sedih, cemas, takut dan khawatir. Namun setelah korban melalui proses terapi healing kemudian muncul kondisi emosi berbeda yaitu menunjukkan kondisi yang lebih baik serta dikuatkan langsung oleh pengakuan korban bahwa jiwanya merasakan suntikan semangat yang memunculkan keinginan untuk terus melakukan kegiatan positif demi hidup di masa yang akan datang. Sebagaimana diungkapkan ibu HT "Setelah saya terlibat dengan KIPPER, kalau tadinya kan hanya ikut arisan-arisan saja terus nanti pulang. Nah, setelah ada mahasiswa UIN 
(Sunan Kalijaga) jurusan kemasyarakatan katanya, kalau tidak salah, ingin ikut andil dan bagaimana nanti bisa ikut memperjuangkan ibu-ibu ini. Terus terang saya merasa senang. Kemudian ada enam mahasiswa UIN ikut jadi relawan, itu saya lebih semangat lagi, karena ada yang masih memikirkan kami-kami ini, gtu." (HT, 2016).

Wawancara tersebut menunjukkan progresifitas kondisi korban setelah penanganan yaitu setelah korban aktif mengikuti perkumpulan yang berulang-ulang dan kegiatankegiatan lembaga KIPPER lainnya. Ibu HT merasakan kebahagiaan yang luar biasa karena disekitar dirinya masih ada orang-orang yang peduli dan mau memperjuangkan hak hidup orang seperti dirinya. Hal serupa juga diungkapkan Ibu FK bahwa "awalnya kita harus bisa membaur, kita harus melakukan apa yang bisa kita lakukan untuk kebaikan, kita menunjukkan kebaikan, kita menunjukkan bahwa saya berjuang tidak mau mengaharap imbalan, jadi kita harus ya sekuat kemampuan untuk kita bisa dilihat mata mereka, bahwa saya itu orang yang dijelekkan tapi ternyata aku berbuat baik, karena aku orang yang baik, tapi setelah di lembaga KIPPER yang saya peroleh dengan adanya teman lembagalembaga lain saya merasa senang" (FK, 2016).

Wawancara menunjukkan emosi narasumber mengalami kemajuan signifikan yaitu dengan beragam usaha telah dilakukan supaya dapat berdamai dengan lingkungan dan masyarakat serta terus membuktikan bahwa dirinya adalah orang baik-baik dan mampu melakukan banyak hal sebagaimana yang bisa orang lain lakukan. Ibu FK bertekat (secara kontino) memberikan pemahaman kepada masyarakat tentang kebenaran dan menjelaskan bahwa persepsi mereka (tentang dirinya) tidak benar. Akibat stigma negatif masyarakat mengganggu stabilitas hidup Ibu FK dan kondisi tersebut dijalani selama puluhan tahun.

Kemudian dipertegas kembali oleh pernyataan bahwa tumbuhnya kepuasan tidak hanya dengan fasilitas kegiatan-kegiatan melainkan juga setelah di lembaga KIPPER mereka dapat berkenalan dengan banyak orang, dari berbagai kalangan. Mulai dari sesama anggota sampai berkenalan dan berteman bak dengan tokoh-tokoh instansi dan lembaga sosial lainnya. Hal tersebut diungkapkan oleh Ibu HT "Terus yang saya puas itu, yaa itu, karena anak-anak dari UIN, sebetulnya dari UIN itu sudah memperjuangkan dari dulu, la saya sekarang malah lebih mantep lagi. Dan itu lebih lega lagi" (HT, 2016). Data tersebut membuktikan bahwa penanganan dan berbagai kegiatan berimplikasi signifikan terhadap kondisi korban yaitu adanya jaminan keamanan yang dirasakan oleh korban sebab semakin banyaknya informasi dan orang-orang yang peduli terhadap kehidupan mereka. Kemudian kesimpulannya adalah adanya kepedulian dan simpati dari lingkungan, bakik keluarga, tetangga, dan masyarakat umum berperanguh besar terhadap kesembuhan korban.

\section{Kognitif}

Adapun barometer dalam menganalisis implikasi kognitif adalah melalui dua hal yaitu kecenderungan rasional dan irasional. Individu atau perempuan yang mengalami tramatik sehingga memunculkan rasa takut, cemas, dan hawatir yang berlebihan dan pada saat itu fungsi kognitifnya mengalami penurunan. Dalam kondisi kognitif yang tidak stabil mereka cenderung akan irasional sehingga korban akan banyak memikirkan hal-hal yang tidak dapat dibenarkan akal dan berbahaya bagi dirinya, namun karena kondisi kognitif tidak rasional sehingga menganggap itu sesuatu yang berhubungan dengan dirinya.

Berdasarkan fenomena di lembaga KIPPER, para perempuan yang kondisi kognitif sebelumnya tidak normal namun setelah mengikuti terapi secara personal ataupun komunal kemudian mereka menunjukkan beberapa kemajuan seperti pola pikir yang rasional yaitu terbukti dengan melakukan sesuatu berdasarkan pertimbangan prioritas dan kebaikan. Sebagaiman diungkapan Ibu HT "saya sangat senang dengan adanya kegiatan koperasi di KIPPER karena dengan itu anggota yang memiliki keterampilan bisa lebih giat lagi, kemudian menjual dan memasarkan lewat koperasi itu to, tapi ini masih perlu banyak perbaikan karena koperasinya masih mengalami kendala”. (HT, 2016). Pernyataan tersebut 
menunjukkan kondisi kognitif yang stabil/normal karena mampu menemukan peluang baru atau mampu berfikir untuk suatu kebutuhan jangka panjang. Kemampuan tersebut tampak pada kejelian mereka dalam memproyeksi program koperasi yaitu mereka mempredisksi bahwa program koperasi mampu memberdayakan para anggota, menjadi ruang mengasah keterampilan, dan koperasi menjadi media pemasaran bagi produk-produk. Mengingat para anggota lembaga KIPPER memiliki keterampilan beragam seperti: menjahit, sablon, membuat pupuk, dan tata-boga. Koperasi juga diinisiasi menjadi tempat penjualan hasil kebun atau pertanian (padi, singkong, jagung, dll), dan selebihnya anggota menjalankan usaha-usaha kecil di rumah.

\section{Kesimpulan}

Berdasarkan pembahasan hasil penelitian dapat disimpulkan ke dalam beberapa poin penting yaitu: 1. Lembaga Kiprah Perempuan menggunakan Self-Healing sebagai metode penanganan pada perempuan korban trauma dengan, menggunakan beberapa teknik, diantaranya: a) Memediasi perkumpulan korban, b) Metode merawat diri, c) Metode batu dan bunga, dan d) Metode peta tubuh. 2. Beberapa implikasi penanganan tehadap korban berdasarkan tiga aspek diantaranya: a) Kondisi psikologis realtif lebih stabil, b) Kondisi emosional lebih terkontrol, dan c) Kondisi kognitif cenderung lebih rasional. Secara umum ketiga aspek tersebut mengalamai perubahan ke arah yang lebih baik.

\section{Daftar Pustaka}

Affandi, Y. (2010). Pemberdayaan dan Pendampingan Korban Kekerasan Seksual Perspektif Al-Qur'an. Semarang: Walisongo Press.

Andari, K. K. (1989). Hygiene Mental dan Kesatuan Mental dalam Islam. Bandung: Mandar Мајu.

Galuh Wandita, K. C. (2015). Melepas Belenggu Impunitas. Yogyakarta: KOMNAS Perempuan.

Hawari, D. (1997). Al-Qur'an Ilmu Kedokteran Jiwa dan Kesehatan Mental. Jakarta: PT. Dana Bhakti Prima Yasa.

Lestari, Y. F. (2016). Gangguan Stress Pasca Trauma pada Korban Pelecehan Seksual dan Pemerkosaan. Jurnal Penelitian Dan Kebijakan Kesehatan Surabaya, 1-16.

Mendatu, A. (2010). Pemulihan Trauma. Yogyakarta: Panduan.

Muhammad, H. (2004). Islam Agama Ramah Perempuan (Pembelaan Kiai Pesantren). Yogyakarta: LkiS.

Natalia Maria. (2012, March). 2011, Kekerasan pada Perempuan Semakin Parah Kompas.com. KOMPAS.Com. Retrieved from https://nasional.kompas.com/read/2012/03/07/16244162/2011.Kekerasan.pada.Perempu an.Semakin.Parah

Peregangan, L. (2016). Simple Yoga Stretches for Daily de Stressing.

Poerwandari, K. (2001). Kekerasan Dalam Pengalaman Perempuan Indonesia. Jakarta: Publikasi Komnas Perempuan.

Rakhmawati, R. R. (2014). Metode Keperawatan Komplementer Hipnoterapi untuk 
Menurunkan Efek Strress Pasca Trauma Tingkat Sedang Pada Fase Rehabilitasi SIstem Penanganan Kegawatdaruratan Terpadu (SPGDT). Jurnal Keperawatan Fakultas Kedokteran Universitas Barawijaya Malang, 170-182.

Saputra, T. S. (2012). Manajemen Emosi: Sebuah Panduan Cerdas Bagaimana Mengelola Emosi dalam Hidup Anda. Jakarta: Bumi Aksara.

Soetady, H. U. (2000). Metodologi Penelitian Sosial. Jakarta: PT. Bumi Aksara.

Thufail, f. I. (2015). Kekerasan, Bencana, dan Trauma. KOMPAS Daily News.

Uyun, Z. (2015). Kekerasan Seksual Pada Anak: Stres Pasca Trauma. In Seminar Nasional Psikologi UMS 2015 - Jilid (pp. 228-238). Universitas Muhammadiyah Surakarta. Retrieved from https://publikasiilmiah.ums.ac.id/handle/11617/6537

Yemy, S. P. (1991). Kamus Besar Bahasa Indonesia Kontemporer (I). Jakarta: Modern English Press. 
https://ejournal.radenintan.ac.id/index.php/konseli http://dx.doi.org/10.24042/kons.v5i2.3356 